\title{
Balancing act: exploring the tone of The Life Aquatic with Steve Zissou
}

Article

Accepted Version

Gibbs, J. (2012) Balancing act: exploring the tone of The Life Aquatic with Steve Zissou. New Review of Film and Television Studies, 10 (1). pp. 132-151. ISSN 1740-0309 doi: https://doi.org/10.1080/17400309.2011.635035 (special issue: Wes Anderson and Co.) Available at https://centaur.reading.ac.uk/26533/

It is advisable to refer to the publisher's version if you intend to cite from the work. See Guidance on citing.

To link to this article DOI: http://dx.doi.org/10.1080/17400309.2011.635035

Publisher: Taylor \& Francis

All outputs in CentAUR are protected by Intellectual Property Rights law, including copyright law. Copyright and IPR is retained by the creators or other copyright holders. Terms and conditions for use of this material are defined in the End User Agreement.

\section{www.reading.ac.uk/centaur}

\section{CentAUR}

Central Archive at the University of Reading 
Reading's research outputs online 
Balancing act: exploring the tone of The Life Aquatic with Steve Zissou (Wes Anderson, 2004)

The Life Aquatic with Steve Zissou is in many ways preposterous. It is full of excesses, moments which trigger an intake of breath that those financing the film were prepared to spend so much money on something as fanciful as this story of a struggling Cousteau, who 'hasn't been at his best this past decade', as he and the crew of the Belafonte pursue the Jaguar shark, and a whole array of other animated fauna. The film has a budget in the region of $\$ 50$ million, a range of stunning locations and sets (including a full size cross-section of the Belafonte), two appearances by a killer whale, and a soundtrack in which one of the key musical elements are the songs of David Bowie sung in Brazilian Portuguese by a member of the ship's crew. It creates a world where marine documentaries are premiered in gilded Italian opera houses, and where Adidas sponsors oceanographers.

The film also features performances from actors who in other contexts have seemed eminently too pleased with themselves. Wide angle lenses noticeably distort a visual field which is populated by characters who could be considered caricatures: an English reporter named Jane Winslett-Richardson, played by Cate Blanchett, Willem Dafoe as intense German engineer Klaus Daimler. It trades heavily in pastiche - the whole film could be considered a pastiche of Cousteau's documentaries, and we see a series of films within the film which certainly fit that description, meticulously created with appropriately graded stock, framing and titles, accompanied by a vintage score.

David Thomson provides a sophisticated version of one view expressed in reviews at the time of the film's release. In the 2002 edition of The New Biographical Dictionary of Film, Thompson had only written three sentences on Wes Anderson: "Watch this space. What does that mean? That he might be 
something one day". $(2002,18)$ Updating this entry via his column in The Guardian on 26 October 2007, with Anderson's subsequent film The Darjeeling Ltd fresh in his mind, Thomson writes:

It was clear that Anderson was smart, shrewd, cool, fashionably affectless, and with his fingers on what you might call the lost pulse. But there was already a hint that his taste for the whimsical could lead to nothing but whimsy. He had a way of quietly evading pain, no matter that his most persistent subject was the failure of family. And rather than arrive at outrage or agony in that search, he was settling for a weird (but very cute) mixture of stoned numbness and absent-minded euphoria.

Another way of considering the film might be to group it with the fin de siècle cinema of the late 1980s and 90s, the force of which hasn't completely diminished in the new century, in which unearned superiority and knowing formal play became defining features of the viewing experience: those aspects of post-modernism in which a cynical eye is turned at the available forms, and a contemptuous one at characters (and by extension, their audience). The period where it seemed that modernist endeavour was no longer possible; which for Robin Wood (1989) could be encapsulated in the differences between Shadow of a Doubt and Blue Velvet; when it felt that all the stories that might exist had already been told. The terrain characterised, by Christopher Sharrett in a contribution to the collection The End of Cinema as we know it: American Film in the Nineties (2001), as 'allusionism'.

Sharrett defines allusionism as 'a central strategy by which the commercial entertainment industry conceals its exhaustion and attempts to protect its legitimacy. Suggesting to the spectator that we are all in on the joke, that the cinema apparatus needs to be exposed, that genre conventions need to be ripped apart is central to rebuilding enlightened false consciousness.' He continues, 
...the prospects for a genuine alternative cinema [seem] rather bleak. Films such as Todd Solondz's Happiness (1998), Alexander Payne's Election (1999) and Sam Mendes' much-overrated American Beauty (1999) show the current bourgeois order as fragile, but treat it with snide contempt, the controlling sensibility being that sympathy is for suckers, the current world composed of 'losers' deserving of each other. $(2001,330)$

Happiness, Election and American Beauty are also points of reference for an influential article which appeared the following year, Jeffrey Sconce's 'Irony, nihilism and the new American "smart" film'. Sconce's 'smart film' is not a simple pejorative, nor a narrow category (including dramas as well as comedies), but rather a 'sensibility' which 'manifests a predilection for irony, black humour, fatalism, relativism and [...] nihilism' (350). The article is mainly concerned with identifying this sensibility, and grounding it in a wider cultural context, and is less interested in making evaluative distinctions between films; Sconce is, however, keen to defend the films against a simplistic dismissal, and to suggest that irony 'is not a passive retreat from politics but a semiotic intervention within politics'. $(2002,369)$ '[T]he anti-irony crowd', be they from the left or right, "often confuses the "apolitical" with politics conducted on new terrain'. $(2002,369,367)$

Some of the formal features which Sconce identifies as being features of the smart film bear a relationship to The Life Aquatic: most particularly what he refers to as 'blank' style, which he defines as 'an attempt to convey a film's story, no matter how sensationalistic, disturbing or bizarre, with a sense of dampened affect'. (359) In an updated and simplified version of the article in Williams and Hammond's collection Contemporary American Cinema, Sconce identifies The Life Aquatic as being 'wholly in keeping with [Anderson's] work from the 1990s', whereas Payne's more recent films 'have seen the director 
temper the arch irony of his earlier films to embrace a more naturalistic comic style (and, in turn, several Academy Award nominations)' (2006, 438)

This is not to say that it is impossible to make distinctions between different kinds of ironic deployment in the movies of this period. In a short piece in Film Comment, predating both of the articles above, Mark Olsen identified characteristics of the prevalent forms of irony in the American cinema of the period, and argued that Anderson's work operated differently. Writing about Bottle Rocket and Rushmore, at the time of the latter's release, he opens his with the words:

Unlike many writer-directors of his generation, Wes Anderson does not view his characters from some distant Olympus of irony. He stands beside them or rather, just behind them - cheering them on as they chase their miniaturist renditions of the American Dream. $(1999,12)$ Anderson differs from filmmakers who 'use an ironic stance to establish their superiority over characters and audience alike', and avoids such films 'overly referential worlds [...] while characters are reduced to ciphers....' 'In a climate where coolness reigns and nothing matters, the toughest stance to take is one of engagement and empathy. Anderson seems to have accepted the challenge.' $(1999,12)$ Olsen also employs the term 'New Sincerity' to describe Anderson's position in the field (17).

The introduction of the phrase 'new sincerity' into Film Studies is generally credited to Jim Collins in an article published rather earlier, in 1993. Collins' new sincerity is also identified in relation to an opposing ironic tendency - 'eclectic irony' - to characterise two different currents in the genre films of the 90s. However, The Life Aquatic (or Rushmore) would be much closer to eclectic irony (the playful and heterogeneous recycling of forms exemplified by Back to the Future III) than Collins new sincerity, examples of which include Dances with Wolves, Hook and Field of Dreams: 'Rather than 
trying to master the array through ironic manipulation, these films attempt to reject it altogether, purposely evading the media-saturated terrain of the present in pursuit of an almost forgotten authenticity, attainable only through a sincerity that avoids any sort of irony or eclecticism.' (257)

In his 2007 book, Post-Pop Cinema, Jesse Fox Mayshark advances a similar idea to Olsen, identifying a group of American directors emerging through the 1990s, 'defying easy categorization, and taking aim in a variety of ways at the tyranny of irony'.

Using some of the same tricks as the postmodern pranksters, they found ways to reveal something more than the workings of their own clever construction. They were generous toward both characters and audience in a way that set them apart. If that meant treading the edge of the pits of gooey sentiment, they were willing to risk it $(2007,5)$.

Post-Pop Cinema brings together Wes Anderson with David O Russell, Richard Linklater, Todd Haynes, P.T. Anderson, Spike Jonze, Charlie Kaufman, Michel Gondry, and more tangentially Sofia Coppola, David Fincher and Richard Kelly. Mayshark distinguishes between these directors and Neil LaBute and Todd Solondz whose work is characterised by 'a moralising bitterness...that is colder and more scaberous than most of the films considered in [the] book [...]' $(2007,7)$.

Mayshark's groupings propose some interesting critical distinctions, but the ensuing study does not engage with the films in a manner that enables us to assess these differences: Post-Pop Cinema aims to cover all of the films of its featured directors, and its high-speed approach encourages superficiality. This may explain why Mayshark speaks of Boogie Nights in the same enthusiastic terms as Bottle Rocket $(2007,5)$. (I have always believed Boogie Nights to be a prime example of the kind of condescension in the depiction of its characters the avoidance of which Mayshark is attempting to celebrate. Though the present article doesn't have the opportunity to explore this case in relation to Boogie 
Nights, I hope at least to make a persuasive argument about some of the ways The Life Aquatic operates differently.)

A recent article which recognises the fundamental importance of tone to making evaluative distinctions between these kinds of films is 'Notes on Quirky' by James MacDowell. In the article MacDowell explores an adjective that has become prevalent in almost every discourse about the independent American cinema of the period, and rephrases Sconce to argue that: 'there is once again "a new sensibility at work in American cinema" (Sconce, 2002: 350), that this sensibility is identified in large part by its tone, and that, at the very least, it is one that deserves our attention' $(2010,14)$. The Life Aquatic is undoubtedly a 'quirky' film, and this article will return to some of the features of the quirky which MacDowell outlines in due course.

MacDowell puts some pressure on Sconce's conception of the tone of the smart (alongside Raymond Williams' notion of 'structures of feeling'), one of "the two chief components that intersect to produce this "sensibility" in current smart cinema' $(2002,351)$. In one passage, in particular, MacDowell re-reads Sconce to differentiate between the smart and the quirky:

One thing I want to take issue with, however, is Sconce's desire to define all the films he mentions in relation to the tone of the smart as he sets it out - in particular those of P. T. Anderson, Wes Anderson, Hal Hartley and Spike Jonze (as well as Terry Zwigoff's Ghost World). All these directors seem to me to be firmly tied to the quirky, a sensibility that has a much more complicated relationship with 'the trope of irony' (2002: 353) than does the smart, and which comes far closer to expressing precisely those attitudes 'sincerity', 'positivity', 'passion' - to which the smart is contrasted. Indeed, this is in fact something Sconce might be seen to hint at himself when he is compelled to use phrases like 'bittersweet' (2002: 350) and 'surprising sentimentality' (2002: 351) to describe the work of Wes Anderson and Terry Zwigoff respectively. $(2010,11)$ 
Through the article, MacDowell moves to characterise what he feels to be the most distinctive quality of the quirky - 'a tone that exists on a knife-edge of judgment and empathy, detachment and engagement, irony and sincerity' (2010, 13). To this end, he provides an attentive reading of the end of Adaptation (Jonze, 2002) which identifies 'an extraordinarily balanced rhetorical combination of an ironic detachment from, and a sincere engagement with, its "happy ending"" $(2010,12)$.

Sconce uses tone to discuss the broad features of a film's attitude to its material, rather than considering its moment-by-moment articulation: a survey article has a natural tendency toward the former of kind of characterisation. MacDowell's article supplements its broad delineation of quirky with moments of closer investigation, enabling it to engage with greater tonal complexity, attending to the way in which different elements might support or qualify each other in specific sequences.

Douglas Pye's work on tone - a significant point of reference for MacDowell - differentiates between 'the dominant or systemic aspects' of tone and 'more local and variable' elements $(2000,12)$. Pye's book-length study 'Movies and Tone' is concerned with both, and explores the latter through appropriately detailed critical analyses. The opening chapter draws on Robin Wood's nuanced discussion of The Deer Hunter (and at this point, specifically its ending) to remind us:

of the implications of whole dramatic contexts and the need to resist reducing meaning to simple alternatives (as in 'affirmation' or 'irony'). It is very often the case that, as Wood puts it, 'a number of elements ... hint delicately at possibilities', and how we respond to the various elements, their grading and their interrelationship will determine how we understand the film. (Pye 2007, 17, quotation from Wood 1986, 288) 
To distinguish between the broader aspect of tone (the 'systemic') and local variations, Pye moves to describe the former as 'mood' and to prefer 'tone' for the discussion of the latter. Mood is, most importantly, 'a sense of the film's overall orientation towards the fictional world and action (serious, comedic, satirical, ironic, and so on), its conventions (generic and stylistic distance) and the audience' $(2007,30)$. Of the latter, '[m]ore specific tonal qualities are implied scene by scene and even moment by moment by the network of decisions that create the fictional world, its characters and events, and present them to the spectator.' $(2007,30)$ Applicable to both mood and tone, Pye proposes four dimensions of tone, 'the attitudes implied to: the film's subject matter; the film's audience; the conventions the film employs or invokes; the film as a film' $(2007,16)$. However, caution is urged as these concepts are introduced, registering they are only critical frameworks for dealing with nuanced matters which may resist straightforward categories: "'attitude" and the different dimensions of tone are indicators of complex relationships implied by any film but they do not correspond to neatly divided aspects either of the film itself or of our experience.' (2007, 31). 'Movies and Tone' provokes three further thoughts which may prove useful in the following investigation: the importance of recognising the affective dimensions of attitude, mood and tone - Pye describes mood as 'involving different dimensions of understanding, with feeling and bodily response playing as large a part as more cerebral processes' $(2007,30)$; an acknowledgement that it is only through critical analysis we can develop a discussion of the complexities involved, and the range of cultural understanding which they draw on; a conviction, nevertheless, that through such an approach that the seemingly intangible qualities of tone can be anchored in the material detail of the film. 
I hope this brief tour through the recent field helps to establish the context for the enquiry which follows: looking at selected of elements of the film systemic and local - with the aim of becoming more precise about the film's tone, and its consequences.

My hypothesis is that The Life Aquatic is a film which escapes from the trap of indiscriminate irony (to borrow Wayne C. Booth's phrase) - despite (or, perhaps, because of) what might be described as eclectic irony in its approach and that the only way to establish such a case is through detailed engagement with sequences $(1961,85)$. Such an investigation may provide evidence relevant for a wider discussion of what we might call 'discriminating irony', where subtle judgements and evaluations can co-exist with engagement with characters and their situations, and where irony is effectively controlled and deployed. The films of Russell, Jonze and Linklater, among others, might also profitably be explored with this in mind - but Anderson's intricate film presents a challenging case in which to consider these ideas.

\section{$\underline{\text { An unexpected encounter }}$}

The sequence of Steve Zissou's (Bill Murray) first meeting with Ned Plimpton (Owen Wilson), the young pilot from Jawbone, Kentucky who may be his son, is a useful place to start. The part of the sequence I wish to look at consists of five shots:

1. The long take in which Ned introduces himself to Steve.

2. The tracking shot which follows Steve as he walks to the prow of the Belafonte, having excused himself from Ned.

3. The closer view of Steve as he lights a joint on the observation deck.

4. The shot of Ned and Steve that follows Steve's return, during which Oseary (Michael Gambon) is introduced to Ned. 
5. The three shot of Steve, Eleanor (Angelica Huston) and Ned.

I have described the first of these shots as a long take, but with the partial exception of the third they all draw on different possibilities of the extended single shot. In the three which show conversations $(1,4 \& 5)$ the uninterrupted take acts as one of a number of mutually reinforcing strategies: the camera is prevented from entering the playing space between the actors, holding the performances at a greater distance as a result, and refusing the rhetorical emphasis of reverse-field cutting to guide our attention to particular details. This makes us work a little harder as spectators - particularly in the first shot, in which important but guarded feelings are present to be observed: the drama concerning the revelation of possible paternity and the extent to which Steve might have been negligent in not previously acknowledging Ned, and the emotional response of each to this momentous encounter.

Frontal playing by Murray and Wilson is naturalised in each of these shots by the handrail, though it is a staging strategy employed across the film. One consequence of this is a sense of performances directed to an audience, especially in the context provided by the long take and the way in which each of these conversations is so self-contained as to be almost a sequence shot. Such blocking is a feature of Anderson's work more generally (and, MacDowell would argue, the wider field of the Quirky) but here it has an extra resonance in its relationship to the films made by Team Zissou - where frontal playing, evident performance and direct address to the camera are frequent. This emerges as one of those areas of decision-making where the relationship between the films made by the onscreen characters and the one we are watching is complicated and developed.

Shot 2 demonstrates other possibilities of widescreen framing and long takes - it gives us Steve in his context, walking most of the length of his boat in an extended tracking shot: red woollen hat, dinner jacket and the backdrop of the 
medieval harbour town at night. The surroundings, impressive to us but seemingly unremarkable to the characters - a real boat, populated by numerous guests, anchored in the reflective waters of the harbour - are complemented by the artistry of the camera movement. The camera's relationship to Steve also gives us a chance to watch how he walks, including a little turn of the head, before he gets to his destination, to ensure nobody is following him.

Another advantage of keeping a distance from the players, and sustaining a single take, relates to the traditions of comic performance and particularly the benefits of seeing a performer's body in space, and in relation to others. These benefits are often drawn upon across the film, often in movement, though an example is provided by Shot 5, where we are able to watch Ned's discomfort as Steve tries to persuade Eleanor in highly personal terms ('his mother just died, plus, we're having some problems') that she should meet Ned, followed by his momentary attempts to diffuse embarrassment by suggesting that he hasn't been listening when it becomes clear that Eleanor hadn't realised that he was already in her presence.

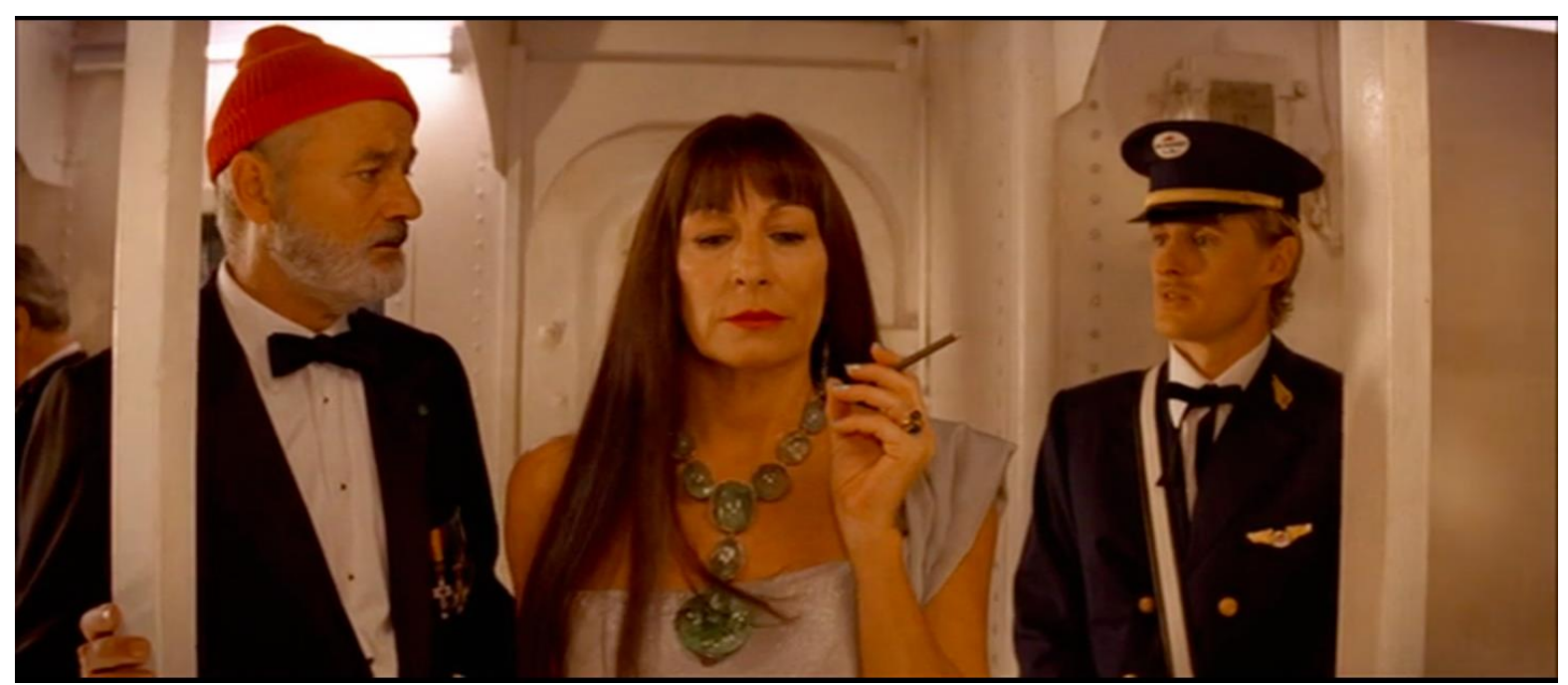

Making reference to MacDowell, for a moment, we can see that some of the features displayed here have a relationship to those more widely observable in his category of the quirky: a preponderance of metacinematic devices and rhetorical self-consciousness; a concern with childhood, or adults regressing to 
childhood, and by extension the family; certain kinds of music - MacDowell picks out one element of Mothersbaugh's score as being typical music of the quirky; deadpan playing and incongruous responses to emotionally weighted events - Oseary's response to Ned might qualify here, if not Steve's. He also draws on Sconce's notion of smart's 'blank style', and particularly 'tableau' presentation,' to characterise visual style in quirky films, foregrounding symmetrical compositions that contribute to the rhetorical self-consciousness of the films' address and impose a 'neat artificiality' (2010: 7). Characterisations can only take us so far, of course, and acknowledging the points of resemblance here - not least as Anderson's films are one of the central points of evidence for MacDowell's definition of the quirky - I want to direct our attention to the specifics of The Life Aquatic.

In Shot 1, when Steve registers what might be at stake in the conversation, he touches Ned on the arm and, looking about him, leads Ned away from the drinks table and toward the ship's rail, which is also in the direction of the camera: the more personal turn of the conversation which follows is thereby more accessible to us while less so to other characters. In this closer framing we can notice Ned's glance away from Steve's eyeline, when Steve claims not to have heard from Ned's mother in 30 years, and the way in which Steve subsequently has difficulty holding Ned's gaze, especially after Ned has responded with the double edged comment, 'Yes, I see', when Steve has claimed never to have been contacted by her. We may also notice the graceful way in which Ned describes his own motives, and the uncertainty in Steve's behaviour - he seems genuinely at a loss in the moments before he excuses himself. 


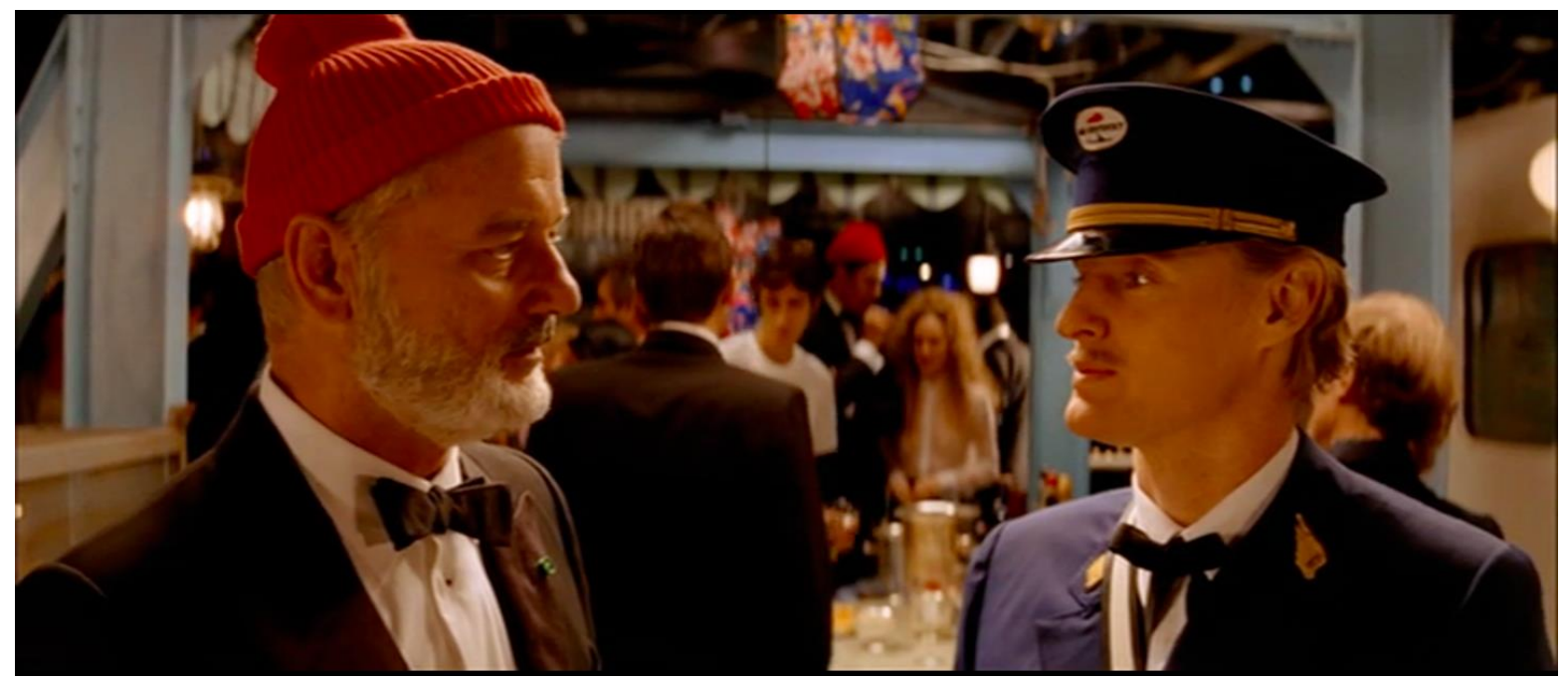

The tonal complexion of the scene is partly achieved by the nature of the performances in the context of the whole. Wilson gives a truthful and unaffected performance here, and throughout the film. Ned stands, sporting a thin moustache, wearing his Air Kentucky uniform, including a narrow ribbon necktie of archaic Southern fashion and a 1960s flight bag, but the character is played without any acknowledgement of the elements of pastiche in the film's approach or consciousness that his character might be less than entirely realistic.

Steve is emphatically the film's central character and the majority of sequences centre on him. Murray's rather particular presence therefore has a significant impact on the film's tone. Deadpan, melancholic, detached, worldweary and sarcastic - the characterisation of Steve draws on these characteristics of the persona at different stages of the film, particularly Murray's detached brand of humour. However, the emotions on display in this sequence couldn't be more removed from the indifference and detachment which are a feature of other Murray performances, or other parts of this performance: Steve seems genuinely disturbed and moved by the encounter with Ned, and has to seek detachment physically, and by means of intoxication. Look closely and you can see he blinks away tears after lighting the joint on the observation deck; Shot 3 is a cut-in which provides a closer view, but it retains a certain distance from the action, picturing Steve from the waist up, with the 
view of the harbour and town behind him, creating a counterweight to the emotive rhetoric of extra-diegetic elements, the film speed ramping to emphasise the moment, and 'Life on Mars' - Bowie's original here - which has swelled in volume as Steve walked along the deck, now in grand rallentando.

It is vital to the tonal qualities of the film - perhaps we should say the mood - that everybody plays their parts straight, without displaying slightest awareness of either the fantastical dimension of the world of the film or the comical events which take place within it, even Jeff Goldblum, whose performance style is often modulated through self-reflective eye movements or gestures of the hand. There is no grotesquerie here, and the film doesn't undermine the conviction of the playing - despite the confection of the world of the film, declining to activate the forms of irony, readily available, where characters are placed in an environment the artificiality of which they cannot perceive. (Where there are moments where we are privileged over the characters, they tend to be rather touching, such as when Bill (Bud Cort) and Hennessey (Goldblum) understand themselves to be waved at by Ned, before he boards the helicopter, when Jane was the intended recipient. On a number of occasions, the camera pans through 90 degrees, transforming what might have been a symmetrical or 'tableau' presentation into a new (and sometimes surprising) perspective on the action, modifying the apparent privilege over the characters which the original composition might have implied.) These are significant aspects of the film's attitude toward its characters, in turn connected to the film's attitude to the fictional world which, despite the extremes of invention and artificiality displayed, is at the same time defined by the care and enthusiasm with which it has been created.

\section{$\underline{\text { Steve }}$}


This is not to say that the film encourages us to view its characters without making evaluations and assessments of their behaviour. In our relationship to Steve, the film offers a tension between tarnished charisma and irresponsibility.

An early incident indicates some of the variables. As Steve goes to leave the premiere, with Eleanor on his arm after a small rapprochement, he is heckled about the death of Esteban (Seymour Cassel). Accosting his tormentor by the throat, he takes a punch on the jaw before several red-hatted members of Team Zissou jump to his defence. Eleanor, who lit a cigarette while Steve rushed to attack, has been watching, but now turns and walks away toward the harbour.

Stepping back from the fray, attending to a minor injury as his crew continue the scuffle off-camera, Steve notices that a plastic bag he has been holding, containing the crayon pony-fish given to him by Klaus' nephew Werner, has been punctured; grabbing an empty champagne flute from a passerby, he decants the seahorse and the remaining water. Holding the delicate, dazzling creature aloft, the glass glinting in the festival lights, he sets off down the redcarpeted steps. In this way he turns an unpleasant and unworthy situation into a small triumph, the crayon pony-fish held high.

The incident introduces some key elements about Zissou and his character, and the ways in which our relationship to him is modulated. His impulsiveness is dramatised: this is hardly the kind of press which he needs at this point, though we know by this point how strongly he feels about the death of his friend and colleague. Eleanor's walk away at the brawl is representative of her response to other moments when Steve behaves in ways which she feels are immature or unwise, and her actions become one of the ways in which Steve's shortcomings are placed in an evaluative framework by the film. The unblinking support of Steve's crew might be difficult to appreciate at this point of the film, but is something we are likely to value before its end. Steve's acceptance of Werner's gift of the pony-fish, and his ability to connect openly with a youthful audience may be one of the things we have found touching in the preceding 
scenes: now Steve doesn't let the scuffle undermine the value of the gift. The pony-fish itself is one of our first encounters with the aquatic life to which Steve has devoted his life: brilliantly coloured, fantastical and unashamedly stop-motion animated, Steve, and the film, nevertheless give it substance.

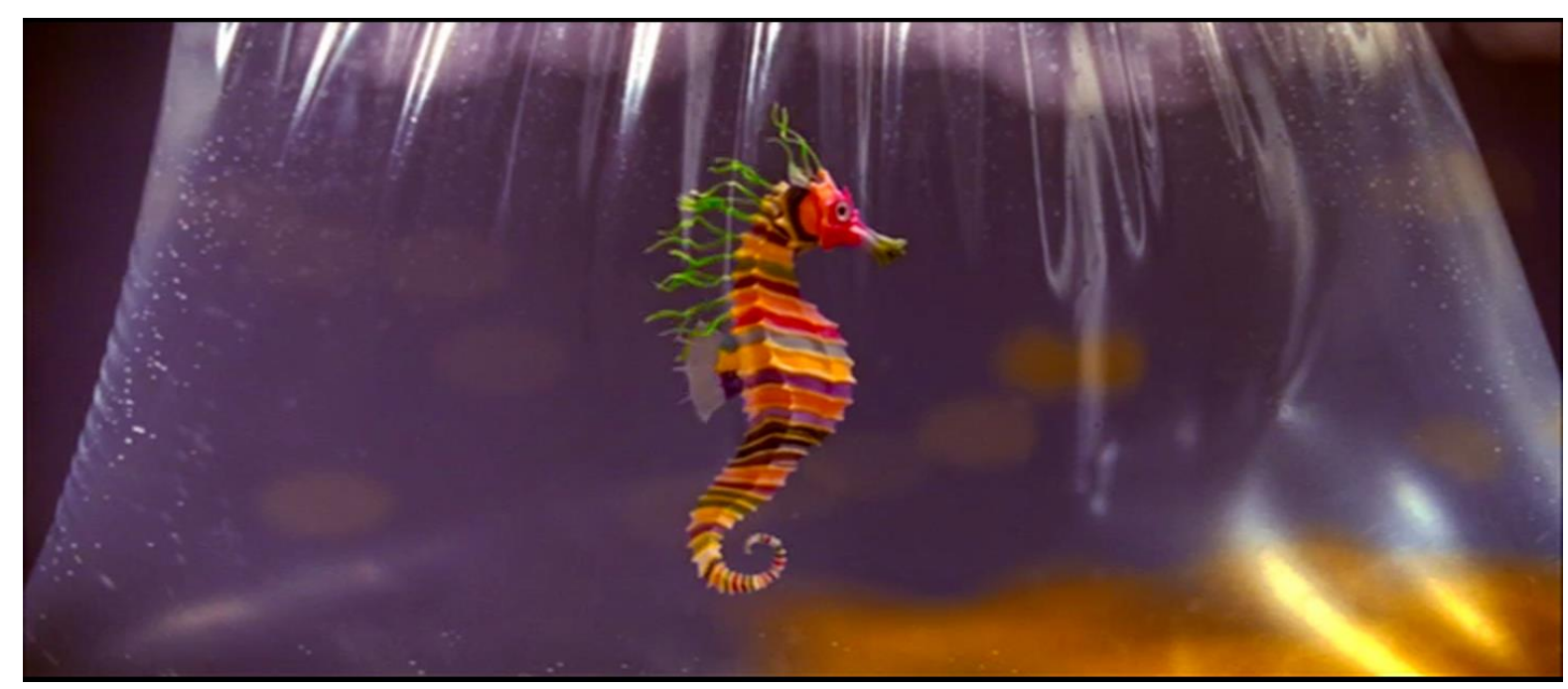

Steve's popularity with children - not only Werner but Ned and Jane have been very taken with The Life Aquatic in childhood and it has shaped their lives - may be related to a certain childishness in his character. This is a man whose favourite age was allegedly 11/2. The pony-fish's Crayola colours are relevant here - the aquatic life of the film suggest something of a child's imagining of the world. Is there a relationship between the handcrafted designs of the ponyfish and the Boys Own life aquatic which Steve has built around himself? We might even suggest that as well as shaping the fictional world of the film he is making, Steve shapes the world of the film we are watching - indisputably the case at the level of Speedos, pyjamas and hats. (Hennessey likes to inscribe his name on the world more authoritatively.) As we encounter the world of Steve Zissou with Ned and Jane, we experience both the beauty and the limitations of the life aquatic.

Steve's behaviour frequently has an adolescent character: his obsessive interest in self-presentation, his impetuousness, his petulant alternation between hitting on Jane and bad-mouthing her on rejection; his forms of argument 
('You're too old for me Steve' - 'Well, you're pregnant'); his selfishness. Team Zissou often feels like a family, especially as it is headed by Steve and Eleanor, and much of the action has the qualities of a family drama. In this context, Steve's behaviour resembles falling into the regressive childhood state which family gatherings can bring about. He sees the 'mutiny' in entirely personal terms: 'Do you all not like me any more? I mean, what am I supposed to do? I don't know.' Paradoxically, Steve's childishness may also one of the things that makes him attractive because the immaturity of much of his behaviour is so recognisable, and so unguarded.

His shortcomings are often placed or implicitly criticised by the film, not just by the responses of other characters - Eleanor, Jane, Ned, Anne-Marie - but also by actions which answer earlier events or through the film's presentation of his inconsistencies. When he has driven the pirates from the ship, he picks up one of his typically contingent forms of abuse, accusing them of being amateurs for leaving their dog behind - later in the film, Team Zissou also leave the dog, now known as Cody, behind on Ping Island as they make their escape.

\section{A careless person?}

A telling episode occurs during a scene on Pescespada Island. Ned has asked Steve when he first heard about him, and Steve has replied with a story of reading about Ned in a newspaper article, some 5 years ago. (We don't yet know that this is also not the whole story, though we might deduce from Murray's performance that Steve is being disingenuous - this is a conversation when reverse field cutting is used, and Steve's dissembling is the more apparent.) Ned then asks why Steve didn't contact him. Steve replies “because I hate fathers and I never wanted to be one", and walks into the corridor. The film cuts to Ned; we see him drop his head and, after a moment, continue polishing 
his shoes. Suddenly Steve enters again frame right, seemingly in a completely different mood, and hands Ned two blue boxes with words, "I forgot - your correspondence stock came in." When Ned opens the box we see that the light blue notecards are headed Kingsley (Ned) Zissou.

The shortcomings of Steve's behaviour are pointed up by our access to Ned's undemonstrative reaction. Given the space to reflect, we may ponder on the gap between what Ned might have hoped for in this conversation and its reality. The poignancy of the scene is not allowed to last, however, as Steve's reappearance establishes another tone, the incongruity of the change in his behaviour and tone of voice, in the context of the preceding action, creating an element of humour. Steve's reappearance indicates a person who is unable to face up, for long, to the emotional consequences of his actions, and who flits back to his own preoccupations rather than being alive to others' feelings. $\mathrm{He}$ pops back in with the notecards as if their arrival will solve the emotional turbulence of moments before.

The notecards themselves are an acknowledgement of his relationship to and with Ned, but one strictly on Steve's terms: in Team Zissou brand, and rewriting Ned's prior history by not only proffering Zissou as a family name, but also pushing Ned's first name into parentheses, replaced by Kingsley. Not for the last time in the film, Steve's desire to control his image and that of his operation take precedence over his relationships. It's also the case that Steve's persistence in referring to Ned as Kingsley - the name he'd have chosen for Ned if he'd 'had a say in it' - contributes to problems later on: without telling anyone, Steve has used his newest crew-member to replace all of his watch duties, but Klaus doesn't recognise the name Kingsley Zissou when he's asked to check the roster shortly before the pirate attack. Our knowledge of Steve's revisions to the roster also gives us a qualifying context when we see him criticising Ned for being in Jane's cabin when he should have been on duty. Steve is someone who will put any argument to use if it suits his purposes at the 
time, and is happy to take the moral high ground when doing so - despite his exploitative relationship to the interns, for example, he says to one of the pirates, 'Don't point that gun at him - he's an unpaid intern.'

Steve is not quite a 'careless person' in the sense that Tom and Nancy are described as being in The Great Gatsby, but he is heading in that direction. It's a quality of the film's tone that we are enabled to hold critical views of Steve while relating to him at the same time.

\section{Embedded in the elements}

The scene when Steve, Ned, Klaus, Bobby (Niels Koizumi) and Vikram (Waris Ahluwalia) dive to investigate the phantom signal provides further indication of some of the textural and tonal balances of the film. In particular, it gives us a good example of how the film's human dramas are mediated by the context of the film's extraordinary world.

The sequence provides a highly unusual mixture of evident stylisation and elements which, while also to some extent artificial, carry a realistic weight. There is no question that action is really taking place underwater, with all of the challenges of realisation which this implies. At the same time, the scene features more of the creatures animated by Henry Selick and his team: a puffer fish which reacts to the black box recorder on the aircraft, a brightly coloured amphibian, a barracuda, and some kind of eel or sea lamprey. The plantlife encountered, also has a distinctly home-made quality - red and pink fronds on the sea bed are accompanied by greeny-yellow trunks reaching toward the light.

The divers are wearing the carefully styled, colour-coordinated sub-aqua equipment which Steve has proudly described to Jane on deck moments before, and their conversation and ability to communicate is mediated by water, masks, aqualung and radio communication. It is through these various forms of baffling 
that an emotionally important drama is played: Ned asks Steve if he can call him Dad 'in this scene' and Steve refuses. This is clearly a heartfelt request from Ned; Steve declines because, he later insists, 'I let you call me Stevsie! It sounds better.'. Having settled on another 'nickname' - the issue is treated as a filmmaking problem by Steve and Bobby ('it's not a bad impulse though, some kind of nickname'), with only Klaus recognising the emotional undertow - the others swim past the camera leaving Ned with his back to us for a long moment, before he slowly turns to follow, one of the animated creatures swimming through the frame as he does so.

This is an important moment in the story of the Ned and Steve's attempts to define their relationship, one of the most significant strands of the narrative of The Life Aquatic (and not just as the 'relationship sub-plot' of The Jaguar Shark, Part 2). But, while not exactly thrown away by the film, our access to this exchange is substantially complicated by some of the other elements of the scene, both in terms of muffling the physical communication between the characters (and us), and by placing it an a range of contexts which qualify any straightforward engagement with the action, including our response to the animated sea creatures - which may involve interest and admiration but which includes an ongoing awareness of their artifice. It is a scene which is shot anglereverse angle, allowing us to get inside the space between Ned and Steve, but this privileged access is counteracted by almost every other decision. 


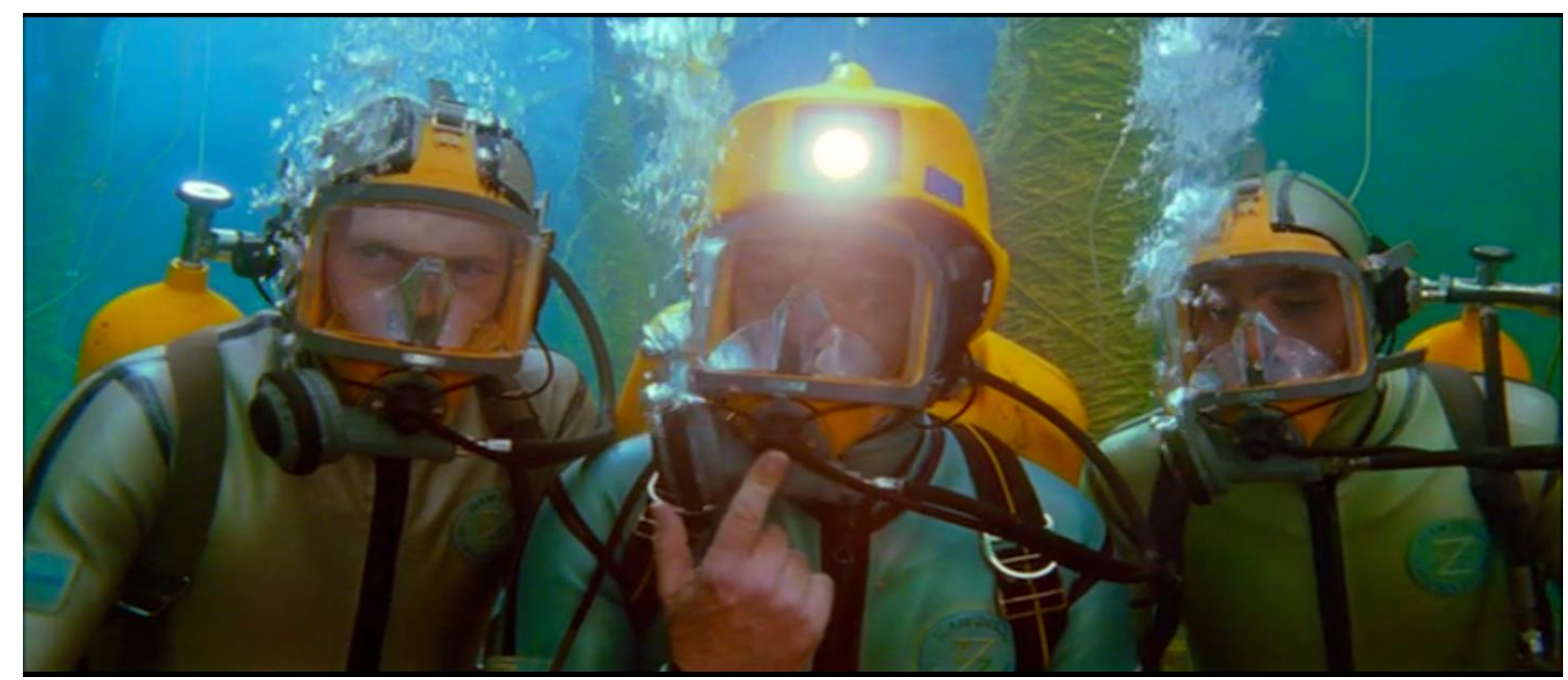

Complicating everything is our awareness of the action being staged for the film that the characters are making, even as they pursue the investigation. Although Vikram may not actually be filming this conversation, he has been instructed to roll the film, and has previously swum into position to catch the shot in which Steve might be called Dad, or Stevsie: the making of the film within the film not only impedes our access to the action but also the action itself - filming the exploration of the sunken aircraft is as least as important as undertaking the exploration. The scene closes with a Steve's voice in commentary on the action - which is then revealed to be a sound bridge to Steve recording the commentary (one of a variety of takes) in the sound booth of the Belafonte.

\section{$\underline{\text { Metacinema }}$}

There are many relationships between the film we are watching and the one Steve is making: the names of the films themselves, the yellow titles which introduce the chronology of the voyage, which are very similar to those used in the films within the film; those occasions, such as the one just described, when picture or sound elements on which the crew are working carry us from one 
scene to the next. Steve's concern with how their activities are being recorded frequently interrupts the action of Anderson's film.

The film offers repeated play with the mechanics of documentary, such as when Ned is resuscitated and the scene ends with the interjection of a light meter and Steve asking the off-screen Vikram at what exposure he has been shooting events. There are also sequences where we realise that the action we have been experiencing 'live' has already been captured by Vikram's camera or Renzo's microphone: 'print both takes, Vikram', Steve ends a scene on Hennessey's research centre; on Ping Island, we move rapidly with Klaus and Pelé (Seu Jorge) as they search for the heavily-armed pirates in a series of hotel rooms, and suddenly encounter Vikram, his camera positioned to anticipate the action.

A lot of fun is had with the fictionality of the documentaries which Steve and his team are producing. At one of his lowest ebbs, having just fallen downstairs, Steve announces that 'we'll give them the reality this time: a washed up old man with no friends and no distribution deal...'. As well as being an anachronistic credit, 'script girl' is an unusual role for a documentary crew, and Anne-Marie's work clearly involves a concern with continuity more common in fiction filmmaking. Casually condescending, the job title embodies something of Steve's dated worldview and mode of production; Anne-Marie's role is to facilitate Steve's control over what happens in the films, and he has little time for the other views she advocates - it's no surprise that she is the only (full-time) member of Team Zissou to quit after the pirate attack.

Then there's the moment when Steve and Ned are having their worst argument, the action playing out as they walk through the ship, only the second time when the Belafonte cut-away set is revealed for what it is, with the camera viewing several cabins at once, and the first time the cross-section view is used diegetically - if that's the right word. Ned: 'You don't know me. You never wanted to know me. I'm just a character in your film.' 'It's a documentary', 
protests Steve, 'It's all really happening!', while Vikram films the exchange through a porthole. It is typical of the film that the one of the most crucial elements in Steve and Ned's relationship is presented through an especially reserved revelation of artifice. The metacinematic play reveals important elements of the film's attitude to the conventions it evokes and to the film as a film, but the distance created feeds into the tension of contrasting approaches developed around our relationship to characters and events.

\section{$\underline{\text { Action Cinema }}$}

An additional element in the film's weighting of tonal elements against one another is the handling of the action sequences which populate its later stages. Again we presented with an intriguing mixture. The sweeping camera movements of the attack on Ping Island, the explosions, the sensation of the helicopter's fall from the air in the fatal accident have a kinetic and affective impact - particularly noticeable when the film is experienced in a cinema. At the same time, moments such the pirate attack are not played for suspense even though all the ingredients are there, including the privileging of the audience over the characters at the moment of the attack - and the most violent passages of action, such as Steve's defence of the Belafonte or the rescue of Bill (Bud Cort) and Hennessey from the island, are emphatically implausible in terms of realistic action, the film making a point in creating insurmountable odds or eliding details of the escape.

In the pirate attack, which becomes markedly more serious with the injury to Ned and the capture of Bill, the negative emotions generated are not fully activated. They are present, but remain tempered by other elements: Steve's / Murray's humour, his ongoing concern with what footage Vikram might have been able to capture, Bud Cort's impressive Filipino. I take this to be an example of what Thomson is referring to when he describes Anderson's 
work as 'affectless' or refers, less charitably, to 'stoned numbness'; it may also have a relationship to Sconce's 'dampened affect'.

There is a distinct break part way through the sequence - when a montage of sounds and images presages Steve's escape from his bonds. The cool blue hue which has characterised the grading of the on-deck sequences of the raid is hereafter replaced by the familiar warm colours of the rest of the film: Steve starts driving the pirates from the ship, and Iggy Pop's 'Search and Destroy' joins in on the soundtrack. Marked shifts in tone are a feature of the film which contribute to the framework of competing tonal elements that make up the whole. Steve's return with the notecards would be one example already encountered. Another would be the interruption of the pirate's burial at sea for the pirate by the arrival of Operation Hennessey, which features one of the 90 degree pans mentioned earlier, on this occasion surprising both us and the characters.

At the same time, this is a world where people die, or are killed in the pursuit of the Belafonte's adventures. The mode of the film may be broadly comedic, but the underlying events are in many respects closer to the melodramatic, to employ Deborah Thomas' terms. Ned's death, in particular, is a scene that many people find extremely moving, both in the moment itself and in its impact on the other characters. It pervades the final sequences of the film, including the encounter with the Jaguar Shark.

The Jaguar Shark, or whatever it is

The scene in the submarine is a rather wonderful culmination of some of these patterns. 


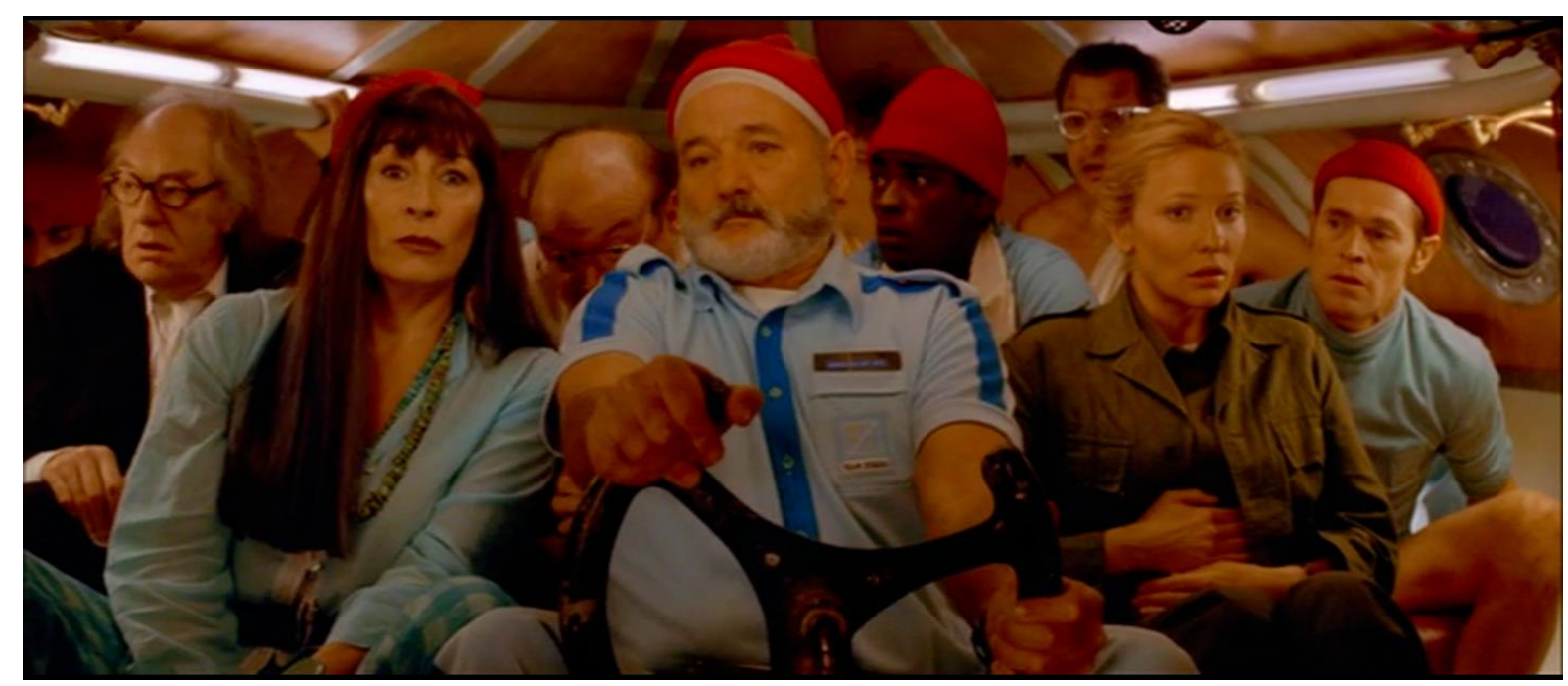

Buffeted by the presence of the shark as it passes overhead, the film foreground's Steve's response, but this is accompanied by our awareness of the other characters, especially the two women who sit on either side of him. The moment pitches an evocation of Esteban and Ned's loss against the conclusion of the Belafonte's quest. The shark does exist, and it is more vast than we could have expected, a wonderful creature previously unknown to science, but one which is also a patently animated creation. We recognise its significance for the characters: it earns precious praise from Eleanor, 'It is beautiful, Steve', the camera tracking in to let us appreciate her reaction.

The elements of artifice on display - from the design of the overloaded submarine to the shark itself - do not nullify a response to the way the assembled mariners reach forward and establish a moment a connection with Steve, offering their support - even Hennessey is moved to join in, becoming an honorary member of the group. Jane's unborn British child is also inducted into Team Zissou, and Jane's own involvement is delineated by a parallel closer view to the one we have just seen of Eleanor.

The seating arrangements of the submarine, and the emotional undertow, are then picked up in the opera box on the return to Loquasto. Rather than take part in the triumph of the film's reception, Steve sits outside on the steps, soon to be joined by the Werner, to whom he gives Ned's Zissou Society ring. The applause for The Jaguar Shark Part 2, drifting from the auditorium, feels 
earned: we haven't seen the documentary, but we have just experienced some of its most compelling material. These feelings carry through to the return to the ship, the credit sequence presenting a mythical - but exceptionally evocative vision of friends and colleagues throwing in their lot with Team Zissou.

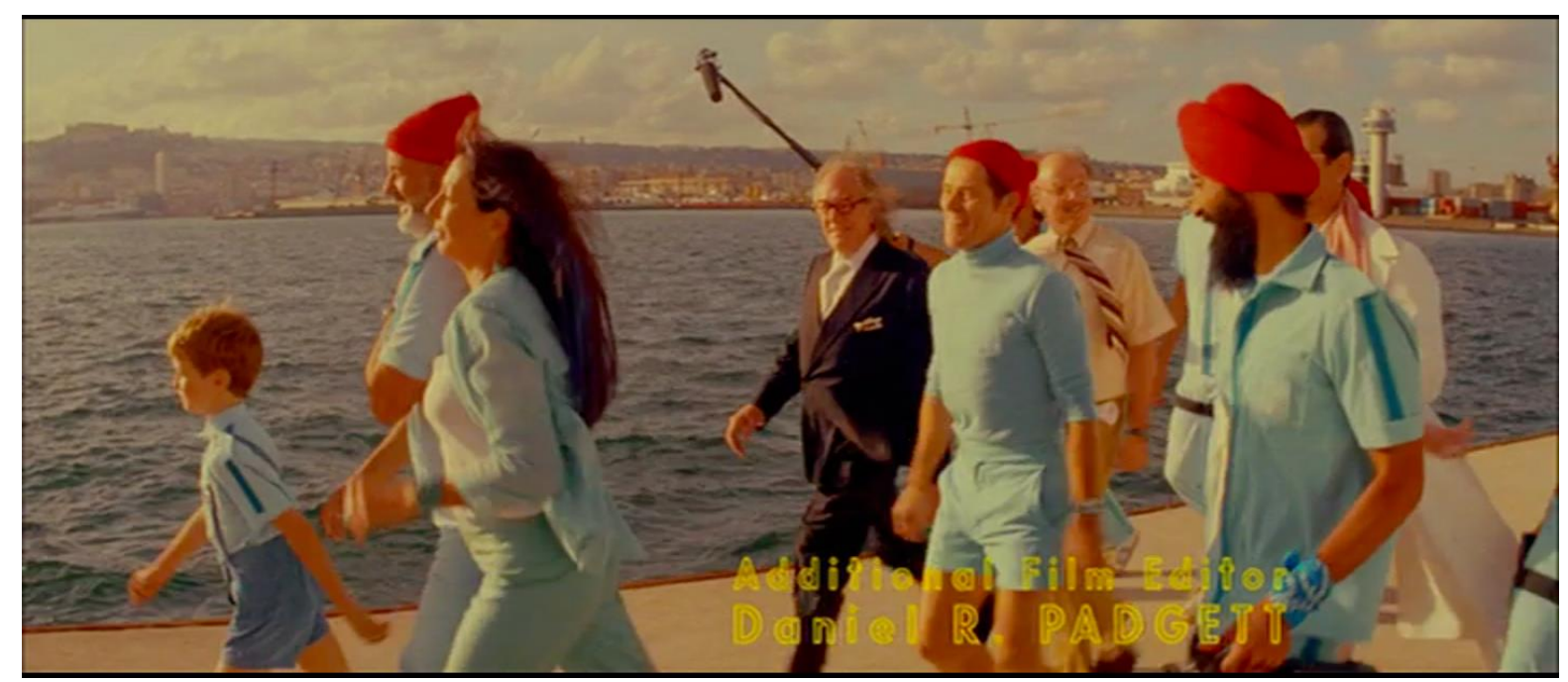

Steve's multi-ethnic 'pack of strays' are a ramshackle bunch, looking for adventure and a sense of belonging. The team more resembles a self-selecting extended family than the professionalism of a Hawksian male group, and it can only function with the presence of Eleanor - the brains of Team Zissou. It is surely preferable to the well scrubbed and well drilled sailors of Operation Hennessey. And by the end of the film it has achieved a new, qualified, heterogeneous unity. This, I would hazard, is why people buy Team Zissou clothing on the internet - not for the ironic value but for the empathetic (or perhaps a bit of both).

\section{$\underline{\text { Conclusion }}$}

Much earlier in the film, members of the crew had sat around the television at Pescespada Island watching a VHS of one of their earlier episodes. Even Klaus, the Steve's most devoted advocate, can only regretfully say, 'that's what it used to be like', and Steve, standing apart in the doorway leaves the room. Can a 
strand of the film be thought of as dramatising post-modern alienation? The characters, and especially Steve, hark back to a glorious past, where their films were well received and actions seemed more effective, from a present in which it's difficult to operate.

By the end of the film, through an infusion of new elements and an acceptance of limitations, Steve has achieved a new unity, of action and of the group, less naive, and less given to attempts at control than before, but wiser. In particular, he has learnt about the limits of self presentation - as he says to Jane, after reading the first draft of her article, 'Well I was a little embarrassed at first. Obviously people are gonna think I'm a showboat and a little bit of a prick. But then I realised: that's me. I said those things. I did those things. I can live with that. You're a good writer Jane.'

In a discussion of one of the films of those arch-ironists, the Coen brothers, George Toles writes:

Whatever help irony can be in showing us how to hold more than one attitude or idea at a time, it can find itself helpless when faced with the task of containing and a moderate surge of fellow feeling. It is good for irony to feel chastened and chased by a force that it cannot comfortably integrate. When irony acknowledges its insufficiency, it is not a case of it being vanquished; it is more a matter of irony being temporarily relieved of his duties. $(2001,280-1)$

Irony doesn't have such an oppositional relationship to fellow feeling in The Life Aquatic, but ironic and empathetic elements clearly temper each other, ebbing and flowing across the movie, and interacting within the moment. Rather than adopting irony as a monolithic mode of address (even one which enables us to hold different kinds of awareness simultaneously) we can think of the film as having a braided collection of tonal and formal elements, which are fluidly 
given greater or lesser emphasis, shaping our access to, and at the same time depending on, the dramatic situation.

If it is the case that a number filmmakers have moved beyond the indiscriminate irony of fin de siècle cinema in recent years, then it is likely that the diverse forms of their films are similarly multi-stranded. An approach where different elements can 'hint delicately at possibilities' is necessary to make subtle discriminations and to avoid reductive presentation of complex dramatic and human situations. (Some of the qualities of tone discussed here are going to have equivalents in many an accomplished film.) What I hope the analysis of this particular film has suggested is that playfulness doesn't have to be infantile, that invoking an awareness of construction, however light-hearted, doesn't preclude an emotional or analytical approach, and that fellow feeling, or even sincerity, doesn't have to be limited to a mythical 'recovery of lost purity' (Collins 1993, 261). The Life Aquatic is playful in its attitude, but it takes its excesses seriously.

This article was developed from a workshop presented at the conference, 'Continuity and Innovation: Contemporary Film Form and Film Criticism', held in the Department of Film, Theatre \& Television, University of Reading, September 2008.

Works Cited: 
Booth, Wayne C. 1961. The Rhetoric of Fiction. Chicago: Chicago University Press.

Collins, Jim. 1993. 'Genericity in the 90s: Eclectic Irony and the New Sincerity' in Jim Collins, Hilary Radner and Ava Preacher Collins (eds) Film Theory Goes to the Movies. New York: Routledge, 242-264.

Mayshark, Jesse Fox. 2000. Post-Pop Cinema: The Search for Meaning in New American Film. Westport: Praeger Publishers.

MacDowell, James. 2010. 'Notes on Quirky', Movie: A Journal of Film Criticism, 1, 1-16.

Olsen, Mark. 1999. 'If I Can Dream: The Everlasting Boyhoods of Wes Anderson', Film Comment, 35, 1, 12-13.

Pye, Douglas. 2007. 'Movies and Tone' in John Gibbs and Douglas Pye (eds), Close-Up 02: Movies and Tone, Reading Rohmer, Voices in Film. London: Wallflower Press, 1-80.

Sconce, Jeffrey. 2002. 'Irony, Nihilism and the New American 'Smart' Film', Screen, 43, 4, 349-369.

Sharrett, Christopher. 2001. 'End of Story The Collapse of Myth in Postmodern Narrative Film' in Jon Lewis (ed.) The End of Cinema as we know it: American Film in the Nineties. New York: New York University Press, pp. 319-31.

Thomas, Deborah. 2000. Beyond Genre. Moffat: Cameron and Hollis. Thomson, David. 2002. The New Biographical Dictionary of Film. London: Little Brown.

Thomson, David. 2007. 'Biographical Dictionary of Film No 25: Wes Anderson' The Guardian, October 26.

Toles, George. 2001. A House Made of Light: essays on the art of film. Detroit: Wayne State University Press.

Wood, Robin. 1989. Hitchcock's Films Revisited. New York, Oxford: Columbia University Press. 
Wood, Robin. 1986. Hollywood from Vietnam to Reagan. New York, Oxford: Columbia University Press. 